\title{
Assessment of World Heritage List Nominations under Country Profile of Turkey
}

\author{
Asst. Prof. Dr. Perihan Paksoy
}

\author{
Beykent University, \\ perihanpaksoy@beykent.edu.tr
}

Doi:10.5901/mjss.2014.v5n13p307

\begin{abstract}
World Heritage List is a vital symbol for States to prove their cultural and natural properties nominated by the three Advisory Bodies of the World Heritage Convention (ICCROM, ICOMOS, IUCN) and the World Heritage Centre. Not only the selected property becomes a flagship for the national protected area, being nominated also encourages the states to provide better techniques for protection, conservation and management. Turkey ratified the World Heritage Convention in 1983. Three properties were nominated initially in 1985. Even though approximately 30 years have passed since 1983, there have been only 11 properties inscribed on the World Heritage List. While comparing the other countries representation on the list, Turkey seems to be presented with a fewer number of properties until now. The researcher with this starting point aimed to analyze the World Heritage List Nomination historical process and complementary policies of Turkey. The method of the study is based upon interviews and documentary monitoring. Interviews with the chairman of UNESCO Turkish National Commission Prof. Dr. Öcal Oğuz and sector experts have been carried out. As a result of these studies, the researcher has identified three major problem areas on the implementation process of World Heritage List. From the findings, it can be concluded that improved site management, well-developed links with ICOMOS, IUCN, ICCROM in coordination with their experts, and offering a property for nomination with an integrated approach including a wider stakeholder perspective, a wider region and perspective could increase the number of the properties nominated in the prospective period.
\end{abstract}

\section{Targeting for World Heritage List (WHL)}

Heritage is a mixture of all the cultural, historical components of the society and has a differentiated significance above all the tourism matters. Heritage is a unique component where in the tourism market; the travellers prefer to see different cultures and places with a long history.

Heritage can be seen as offering something more or different to both the tourist and the community. Heritage is significant to different communities, groups and individuals depending upon their value and attitudes and the nature of the heritage resource and is also significant in the future of further tourism development in the region. There is increasing evidence that costs and benefits from tourism do not accrue equally to residents (Kala, 2008: 66). This deeper understanding of the historically contingent and embedded nature of heritage allows us to go beyond treating heritage simply as a set of problems to be solved, and enables us to engage with debates about the production of identity, power and authority throughout society (Harvey, 2001: 319).

Rather than travelling to cliché destinations, unique universal highlighted sites attract many visitors. As all the nations place a crucial importance in their cultural reflection among all the other countries, World Heritage Listings become a list of pride where the countries compete to be involved in World Heritage Lists as well. A World Heritage Site is a place listed by UNESCO as culturally and/or naturally significant. Yet the protection of these heritages often remains incomplete at the national level, especially in developing and less developed countries. In noting this tough phenomenon of damage as well as inadequate conservation, the World Heritage Convention of UNESCO launched an initiative in 1972 to preserve heritage sites considered to be of great value to humanity. The Convention enacted an international treaty called "the Protection of the World Cultural and Natural Heritage" and began to ratify sites on the WHL in 1978. (Huang et al, 2012: 1451) Cultural heritage, as is defined by the 1972 UNESCO Convention on the Protection of the World's Cultural and Natural Heritage, is the complex of monuments, buildings and archeological sites "of outstanding universal value from the point of view of history, art or science" (Peleggi, 1996: 432)

Creating the evidence-based nomination documents and management plan in support of formal submissions to UNESCO for inclusion on the tentative lists compiled by States Party to the World Heritage Convention (UNESCO 1972) demands in-depth research in order to establish 'outstanding universal value'. And, following inscription on the World Heritage List, continued research is encouraged within the wider context of protecting, conserving and presenting cultural and natural heritage, and giving it a function in the life of the community. (Darvill, 2007: 437)

In order to accomplish in maintaining and protecting the heritage sites, for all the destinations and countries the 
capacity for adaptation is required as one of the assets. As a consequence of the greater prominence and recognition accorded to World Heritage, there is also a growing range of tendency and target in being nominated as a World Heritage Site (World Heritage Resource Manual, 2011: 1). At the heart of this world heritage movement is the belief that certain natural and cultural wonders are the collective property and responsibility of all humanity, despite having vastly different historical and geographical origins. What is more, this movement has helped foster a unique feature of contemporary globalization-the recognition of a common, universal heritage to which all societies contribute (Elliott and Schmutz, 2012: 256). The designation is considered important especially when attempting to create a cultural image associated with a site (Ung \& Vong, 2010).

Some other possible benefits from World Heritage status are: (World Heritage Resource Manual, 2011: 10).

- providing an opportunity for the State Party and for the local community to celebrate the property as one of the most important natural and cultural places on Earth;

- The property often becomes a flagship for the national protected area / site system, including a deeper recognition and better protection for heritage in the life of the community;

- International interest in World Heritage often provides a stimulus for international cooperation and joint efforts to ensure the protection of the property;

- Providing opportunities to mobilize funding and support, including from donors, and the World Heritage Fund; and

- Providing techniques and practices for protection, conservation and management that can be applied to national and local heritage properties.

Furthermore for all these nations with an aim of targeting to be nominated, it is commonly believed that being listed on the World Heritage List (WHL) results in attracting more tourists (Huang et al, 2012: 1450). According to Su and Lin (2014: 47), WHSs have been found to have significantly positive effects on the promotion of domestic or foreign tourism in some specific countries, such as England (e.g., Herbert, 2001; Mclntosh and Prentice, 1999), China (e.g., Li, Wu, \& Cai, 2008; Yang, Lin, \& Han, 2010) and Germany, Hungary and Romania (Light, 2000).

In order to keep the historical values and assets maintain for future generations sustainable management of historical sites need to be accomplished. It is essential that an integrated holistic approach to sustainable development and management that incorporates the views and involvement of principal stakeholders such as local residents be adopted (Nicholas et. al., 2009).

UNESCO world cultural heritage sites, in particular landscapes, impose several land use restrictions and consequently impact the welfare of various stakeholders (Lourenco- 0-Gomesa, 2014: 64)

\section{Interview with the President of the Turkish National Commission for UNESCO}

In this part, the researcher has tried to analyze how objective this nomination process takes place with in-depth interview. This questioning of WHL had been previously studied by Le' on Pressouyre (1996), too. He raised his concerns over the Convention's application, the meaning of variables such as authenticity and integrity, and the extent to which the list remained valid, but the need for thorough research remains central (e.g. Pressouyre 1996: 33-7). Simultaneously, UNESCO's World Heritage project has been viewed as an example of international dominion, or more specifically, a Western colonial mission (De Cesari, 2010; Meskell, 2002; Rowlands \& Butler, 2007). Even the meaning of variables and the authenticity of World Heritage project have been questioned by some researchers; some academicians proposed a different view as well such as Reyes (2014). Reyes (2014: 43) believe that created and diffused by UNESCO, it is of particular interest because rather than being the product of a single player or group, the list of sites is, in theory, the democratic outcome of a global debate on culture and politics.

In this study the researcher has conducted an interview with Prof. Dr. Öcal Oğuz, President of the Turkish National Commission for UNESCO on 25 $5^{\text {th }}$ April, 2014 about the World Heritage Sites representation throughout the World and tried to come up with conclusion on the main reasons why Turkey has relatively low depiction in the World Heritage List.

Some highlighting points discussed in the interview are as follows:

Paksoy: Why Turkey with an ineradicable cultural and historical background is presented in the World Heritage List with a comparatively low numbers compared to other European countries? Why Sümela or Bergama and many other historical values are not placed in the World Heritage List?

Prof. Dr. Oğuz: Turkey signed the World Heritage Convention in 1983. Till 1987 Turkey had been in the World Heritage Committee (WHC). After then, theoretically if Turkey had proposed even one candidate for each year, now the number of World Heritage List Turkey is presented with would have been 32. Hence it would not be a mistake to point out 
that time has not been managed properly for offering a World Heritage asset to the Committee. Countries like Italy and Spain, etc. have offered not only one, but more than at least one. Some countries had recoursed to the World Heritage Committee with more than 5 candidates. Previously the selection and nomination criteria were easier. And most of those countries as a result of their former efforts are now awarded with a more favourable list. What is more, even we do our best to carry out research and pointing out World Heritage candidates, WHC has defined certain quotas for a year and even if you are prepared with more candidates, you can not apply to WHC over the quota. In cultural assets we can apply with 2 sites and for natural nomination the quota is only 1.

Paksoy: What does WHC give emphasis in determining WHL? Are there any new criteria that they seek for during the nomination process?

Prof. Dr. Oğuz: WHC pursues an integrated study in which the intangible heritage asset is in harmony with the tangible one. They don't prefer copy-pasted files indeed they expect reports where a team of experts have indicated their comments and study in detail. They dignify projects which represent an earlier historical period such as rather than a 19th century timbered traditional house, they esteem uniqueness. 16th century city walls display similarity among all the destinations. Thus these type of assets need to be demonstrated with a series study like a city wall and any other asset nearby which could present distinctiveness as well. Or the candidate for the nomination can be suggested "as of the Seljuks". In this proposal there can be Konya Alâeddin Mosque, Niğde Alâeddin Mosque, Sivas Ulu Camii, Afyon Ulu Mosque, Amasya, Gökmedrese Mosque etc. Another proposal can be regarding a scenic route. Castles of Genoa could be one of the options for this kind of a study.

Paksoy: What are the advantages of Turkey in regards of WHL that could be emphasized?

Prof. Dr. Oğuz: We have 13 properties inscribed on the World Heritage List. The cultural assets listed are 11.

- Archaeological Site of Troy (1998)

- Bursa and Cumalıkızık: the Birth of the Ottoman Empire (2014)

- City of Safranbolu (1994)

- Great Mosque and Hospital of Divriği (1985)

- Hattusha: the Hittite Capital (1986)

- Historic Areas of Istanbul (1985)

- Nemrut Dağ (1987)

- Neolithic Site of Çatalhöyük (2012)

- Pergamon and its Multi-Layered Cultural Landscape (2014)

- Selimiye Mosque and its Social Complex (2011)

- Xanthos-Letoon (1988)

The Mixed Assets are only two

- Göreme National Park and the Rock Sites of Cappadocia (1985)

- Hierapolis-Pamukkale (1988)

Additionally Turkey is advantageous with its tentative list. Turkey has 52 tentative heritage assets. And besides in none of our application we had been treated with a refusal. Turkey is a rich country with both tangible and intangible assets. Turkey signed intangible heritage list in 2003. Between the years 2008-2013 we have reached a record of 11 intangible assets in which Turkish coffee even has taken its place. In natural heritage assets last year Tuz Gölü-Salt Lake have been nominated under the tentative list.

Furthermore Turkey has been elected one of the 21 States Parties of the current World Heritage Committee. The committee members are the following: Algeria, Colombia, Croatia, Finland, Germany, India, Jamaica, Japan, Kazakhstan, Lebanon, Malaysia, Peru, Philippines, Poland, Portugal, Qatar, Republic of Korea, Senegal, Serbia, Turkey, and Vietnam.

But still it can be concluded that improved site management, well-developed links with ICOMOS (International Council on Monuments and Sites), IUCN (International Union for Conservation of Nature), ICCROM (International Centre for the Study of the Preservation and Restoration of Cultural Property) in coordination with the support of experts may help to increase the number in WHL.

\section{Evaluation of the Interview and Concluding Remarks}

In his speech, Prof. Dr. Oğuz mentioned that unfortunately there had not been adequate study about WHL in the earlier periods of the WHL process of Turkey. Now that there is a certain quota to apply to the WHC, even though there are prepared projects to can be proposed, there cannot be application more than 2 cultural assets and 1 natural asset for a year. Thus the WHL of Turkey is represented as 13 in total. Oğuz also mentioned about the route and series product. In 
historic towns it is almost always the value of group or collection of buildings that is more important than the architectural value of each building (Orbaşlı \& Woodward, 2009: 318). Given that this "route" is a tourist product, it also generates a demand for an exact "identification" of the network and pressure for the coordinated provision of complementary visitor services, which may become a complex issue as the extension of the network or route stretches beyond regional or national borders (Romagosa and Russo, 2008: 60).

Creation of routes and series studies can easily be realized in Turkey with the country's rich historical collection of sites and values.

The researcher in this perspective highlighted some suggestions for future proposals in WHC study. The integrated and sustainable areas and sites that could be recommended are consequently as follows.

- Caravanserais of Anatolia

- The Mevlevi Teachings and Related Places

- Architectural Works of Mimar Sinan-Master Builder

- Ottoman Works Built in Fatih-The Conqueror of İstanbul ( this could be further researched for other sultans as well)

It can be concluded that improved site management, well-developed links with ICOMOS, IUCN, ICCROM in coordination with the support of experts in improving projects like series or route with an integrated approach may help to increase the number in WHL.

Future research, including the design of a series of small-scale studies, could also contribute to further amplification of the effects of Word Heritage Sites. For example, exploring the designation effects on visitors' on-site behaviors could also bring an insight for the importance of WHL.

\section{References}

Darvill, T. (2007). Research frameworks for World Heritage Sites and the conceptualization of archaeological knowledge. World Archaeology, 39(3), 436-457.

De Cesari, C. (2010). World heritage and mosaic universalism: A view from Palestine. Journal of Social Archaeology, 10, $299-324$.

Elliott, M. and Schmutz, V. (2012). World Heritage: Constructing a Universal Cultural Order, Poetics, 40, 256-277.

Harvey, D. (2001). Heritage Pasts and Heritage Presents: temporality, meaning and the scope of heritage studies. International Journal of Heritage Studies, 7(4): 319-338.

Huang, C., Tsaur, J. and Yang, C. (2012). Does world heritage list really induce more tourists? Evidence from Macau. Tourism Management, 33, 1450-1547.

Kala, N. (2008). Host Perception of Heritage Tourism Impact with Special Reference to the City of Jaipur. South Asian Journal of Tourism and Heritage, 1(1), 65-74.

Lourenco- 0-Gomesa, L., Pintob, L. Rebelo, J. F. (2014). Visitors' preferences for preserving the attributes of a world heritage site. Journal of Cultural Heritage, 15, 64-67.

Meskell, L. (2002). Negative heritage and past mastering in archaeology. Anthropological Quarterly, 75(3), 557-574.

Nicholas N. Lorraine, Brijech Tapa and Yong Jae Ko (2009), Residents' Perspectives of A World Heritage Site: The Pitons Management Area, St. Lucia, Annals of Tourism Research, Vol. 36, No:3, pp. 390-412, 2009

Orbaşlı \& Woodward (2009). Tourism and Heritage Convention. In Tazim Jamal \& Mike Robinson (Eds) The Sage Handbook of Tourism Studies (pp. 314-332). Los Angeles: Sage.

Peleggi, M. (1996). National Heritage and Global Tourism of Thailand. Annals of Tourism Research, 23(2), 432-148.

Pressouyre, L. (1996). The World Heritage Convention, Twenty Years Later. Paris: UNESCO.

Reyes, V. (2014). The production of cultural and natural wealth: An examination of World Heritage sites. Poetics, 44, 42-63.

Romagosa, F. \& Antonia P. Russo (2008). The Advantages of Sharing: A case study of the Jewish heritage network in Spain, In Verbeke, J. Miriam and Gerda, K. Priestly, (Eds.), Cultural Resources for Tourism: Patterns, Processes and Policies (pp. 59-78). New York: Nova Science Publishers.

Rowlands, M., \& Butler, B. (2007). Conflict and heritage care. Anthropology Today, 23(1), 1-2.

$\mathrm{Su}, \mathrm{Y}$. and Lin, H. (2014). Analysis of international tourist arrivals worldwide: The role of world heritage sites. Tourism Management, 40, 46-58.

Ung, A., \& Vong, T. N. (2010). Tourist experience of heritage tourism in Macau, China. Journal of Heritage Tourism, 5(2), 157-168.

World Heritage Resource Manual (2011). Preparing World Heritage Nominations. Second Ed. Paris: UNESCO 